\title{
A New Quadratic Boost Converter with Voltage Multiplier Cell: an Analysis and Assessment
}

\author{
Muhammad Zeeshan Malik ${ }^{*}$, Amjad Ali, Qunwei Xu and Guozhu Chen \\ College of Electrical Engineering, Zhejiang University, Hangzhou, China \\ malik4one@yahoo.com
}

\begin{abstract}
A new topology of high gain DC-DC quadratic boost converter with voltage multiplier cell $(V M C)$ is introduced in this paper. The proposed VMC technique is derived from the traditional quadratic boost converter, which has an advantage with high oltage gain and stress across the semiconductor devices are lower than the output voltage. To validate efficacy of the proposed method simulation has been performed in Mat lab Simulink software to compare the voltage gain of proposed method with others five modified boost converters. The input voltage of proposed converter'and other topologies are same IOVDC but the output voltage of proposed converter is much higher than others converters which are discussed in this paper.
\end{abstract}

Keywords: Quadratic boost converter, Voltage multtielier cell, high voltage gain, voltage stress

\section{Introduction}

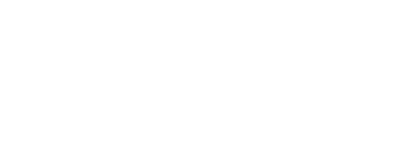

Usually renewable energy technologies RETs, particularly solar photovoltaic PV system demand high step up voltage/conversion. Because of solar PV fluctuated output voltage under non-uniform solar conditions DC-DC boost converter has attracted the intention of research in recent year [1-4]. Therefore, different types of DC-DC converter are being used to attain the required and stable output voltage. To mitigate the aforesaid disadvantage of conventional boost converter, so far many solutions are proposed and successfully implemented to get the high voltage step up ratio, such as forward or fly back converter is discussed 1n [5]. The disadvantage of this type of converter is transformers which increase the losses, cost and size [6]. In [7] conventional quadratic boost converter is proposed which use only one switch for voltage conversion ratio, the voltage gain of conventional quadratic boost converter is not much high and they present voltage and current overstress when the conversion ratio is high. In [8] tapping Boost converter with couple many inductors in presented to achieve the high step up voltage by adjusting turn ration. The disadvantage of this type of converter is difficult to couple inductors and leakage inductance occurred, the problems overshoot the large voltages [9].

The non-insulated converter has an advantage over insulated converters, the cost of non-insulated converter is lower than insulated converter and efficiency is high. The disadvantage of non-insulated converter is the input current and output voltage is high, at this situation the switches need to be sized according to input current and output voltage for high voltage gain. The sizing of switching is expensive that's why at some point insulated converter are better option [10]. In [13-15] cascaded converter for PV and fuel cell is presented, but the disadvantage of cascaded converter is its high cost and also compromise on efficiency.

A new topology of quadratic boost converter with voltage multiplier cell (VMC) is introduced in this article; the advantage of the proposed topology over the conventional quadratic boost converter and other modified converters which are presented in this paper has high voltage gain, and the voltage stress across the switches is lower than output 
voltage. According to conventional quadratic boost converter the voltage stress across the switch $\mathrm{S}$ is equal to $\mathrm{V}_{\mathrm{S} \text {-stress }}=\mathrm{V}_{0}$ and the voltage stress of proposed the converter is $\mathrm{V}_{\mathrm{S} \text { - }}$ stress $=\mathrm{V}_{\mathrm{C} 2}$ which are lower than output voltage, similarly stress across the diode $\mathrm{D}_{3}$ in conventional quadratic boost converter is $\mathrm{V}_{\mathrm{D} 3}=-\mathrm{V}_{0}$ and stress across the diode in the proposed topology is $\mathrm{V}_{\mathrm{D} 3}=-\mathrm{V}_{\mathrm{C} 2}$. The proposed (VMC) topology shows an enhancement of the high voltage gain over the some topologies presented in [1-11-12-14-16] with same duty ratio at $\mathrm{D}=0.6$.

\section{Traditional Boost Converter}

The traditional boost converter circuit diagram is depicted in Figure-1, which is mostly used for step up voltage in conventional applications [11]. The main disadvantage of this type of converter is for high step up conversion need high duty ratio, which causes the difficulties for switching frequency because of limitation of OFF time of semiconductor switch.

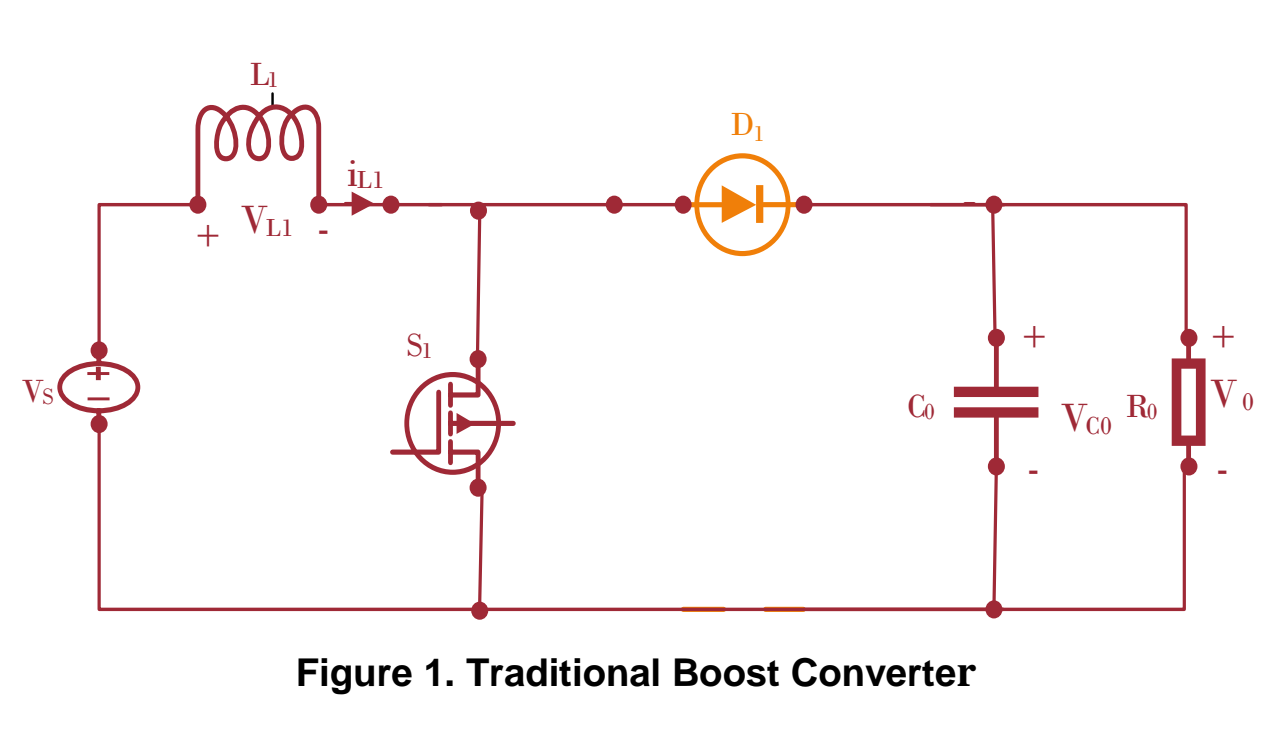

Voltage gain of traditional Boost converter is obtained by (1):

$$
M=\frac{\mathrm{V}_{0}}{\mathrm{~V}_{\mathrm{s}}}=\frac{1}{2(1-D)^{2}}
$$

\section{A Boost Converter with Voltage Extension Cell}

n Figure-2 boost converter with extension cell module is depicted. It contains two additional switches (Sa-S1), diode (Da) and capacitor (C1). This converter is derived from traditional boost converter; the advantage of this converter over traditional boost converter has high voltage gain [1]. 


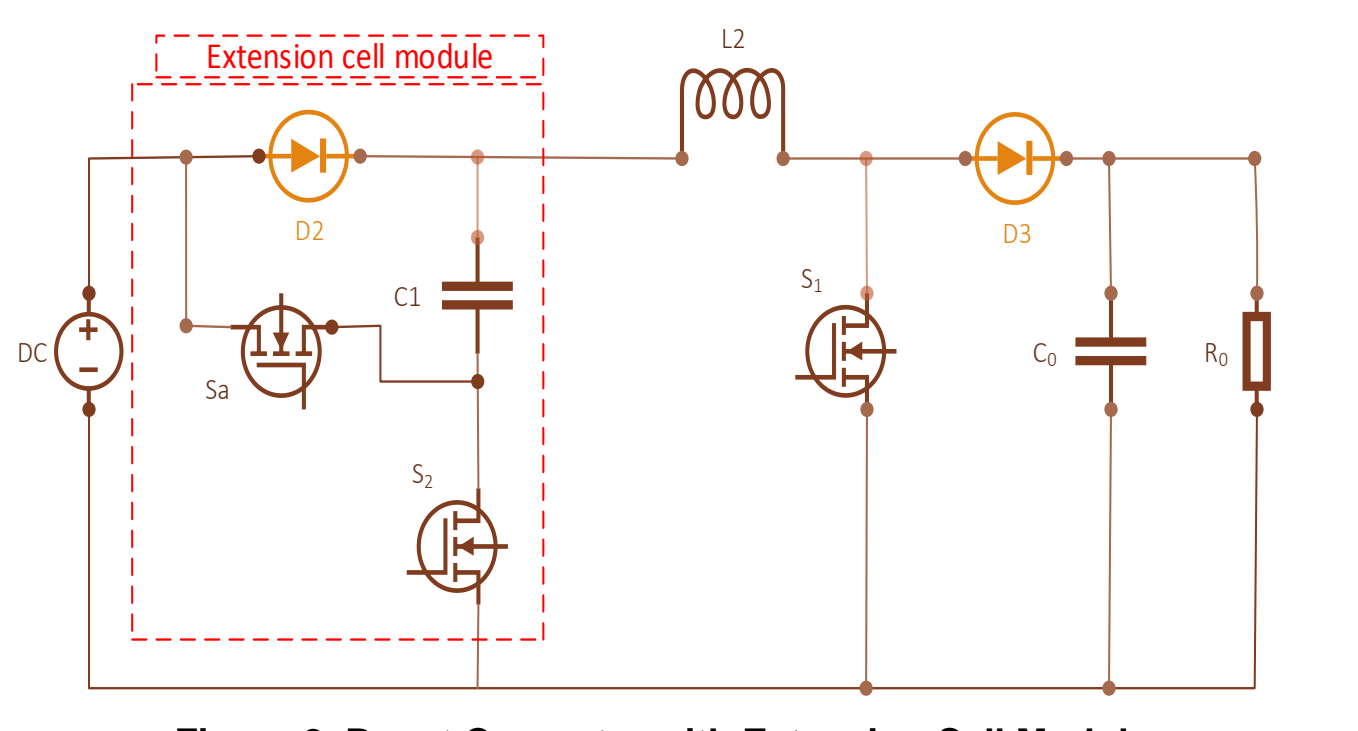

Figure 2. Boost Converter with Extension Cell Module

The operation of this converter work with fixed switching frequency $100 \mathrm{kHz}$ and the switching period is $T_{s}$. The semiconductor switches $S_{a}, S_{1}$ and $S_{2}$ turn ON and OFF with two PWM signals. $S_{2}$ and $S_{1}$ are operated at one PWM signal and the $S_{a}$ is operated by $2^{\text {nd }}$ PWM signal, which is the inverse of $1^{\text {st }}$ PXNM.

The voltage gain of this converter is,

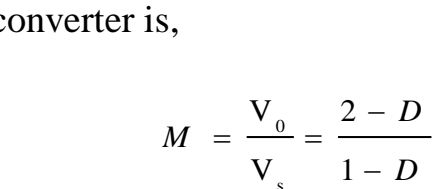

\section{Boost Converter with Voltage-Lift Cell}

Boost converter with voltage-lift-cell is shown in Figure 3; the advantage of voltage lift cell over traditiona boost converter is high voltage gain with decreased stress across the switch. As compared with Graditional boost converter, two additional capacitor and two diodes are employed in the,voltage-lift cell as depicted in Figure 3.

The operation of bogst converter with voltage lift cell work in continuous conduction mode (CCM), in ${ }^{\mathrm{tt}}$ state when switch $\mathrm{S}$ is $\mathrm{ON}$ at this time input voltage source delivered supply voltage to inductor $\mathrm{L}_{1}$ at the same time capacitor $\mathrm{C}_{2}$ and $\mathrm{C}_{1}$ are in charging mode with supply voltage. When switch $\mathrm{S}$ is in OFF mode inductor $\mathrm{L}$ delivered the stored energy to capacitor $C_{1}$ and the other capacitor $C_{2}$ in this stage is in discharging mode to load respectively. 


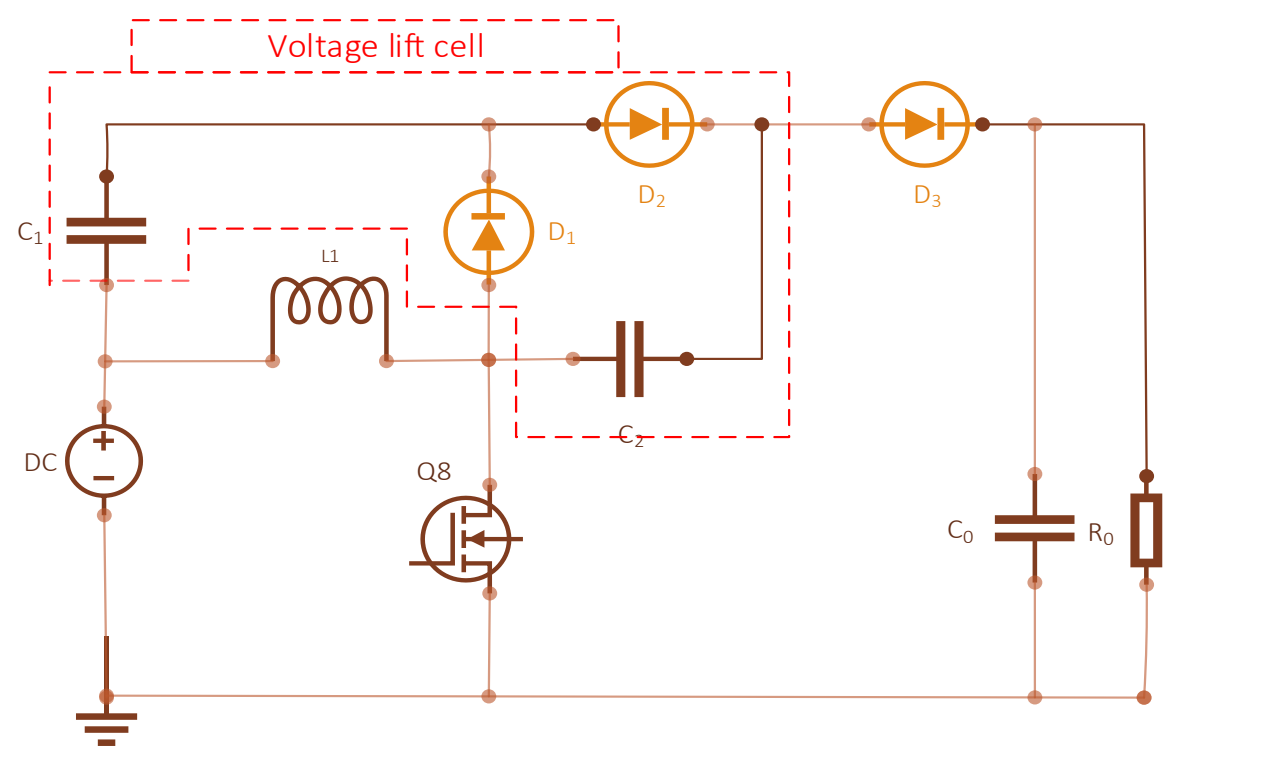

Figure 3. Boost Converter vith Voltage Lift Cell

The voltage gain is

Voltage gain of this converter is ligher than the traditional boost converter and have advantage reduces losses over semiconductor devices which increase the life time of converter [12].

\section{Traditional Quadratic Boost Converter}

Traditional quadratic boost conventer circuit is depicted in Figure 4. Its consist 1 switch $\mathrm{S}, 2$ inductors $\mathrm{L}_{1}, \mathrm{~L}_{2}, 3$ diodes $\mathrm{D}_{1}, \mathrm{D}_{2}, \mathrm{D}_{0}$ and two capacitors $\mathrm{C}_{1}, \mathrm{C}_{0}$ respectively. This quadratic boost converter ean enhance the high voltage gain work with only 1 switch $\mathrm{S}$ [14]. The voltages stress on switch $S$ is equal to output voltage. This converter can produce over voltage and current overstress when voltage gain is high.

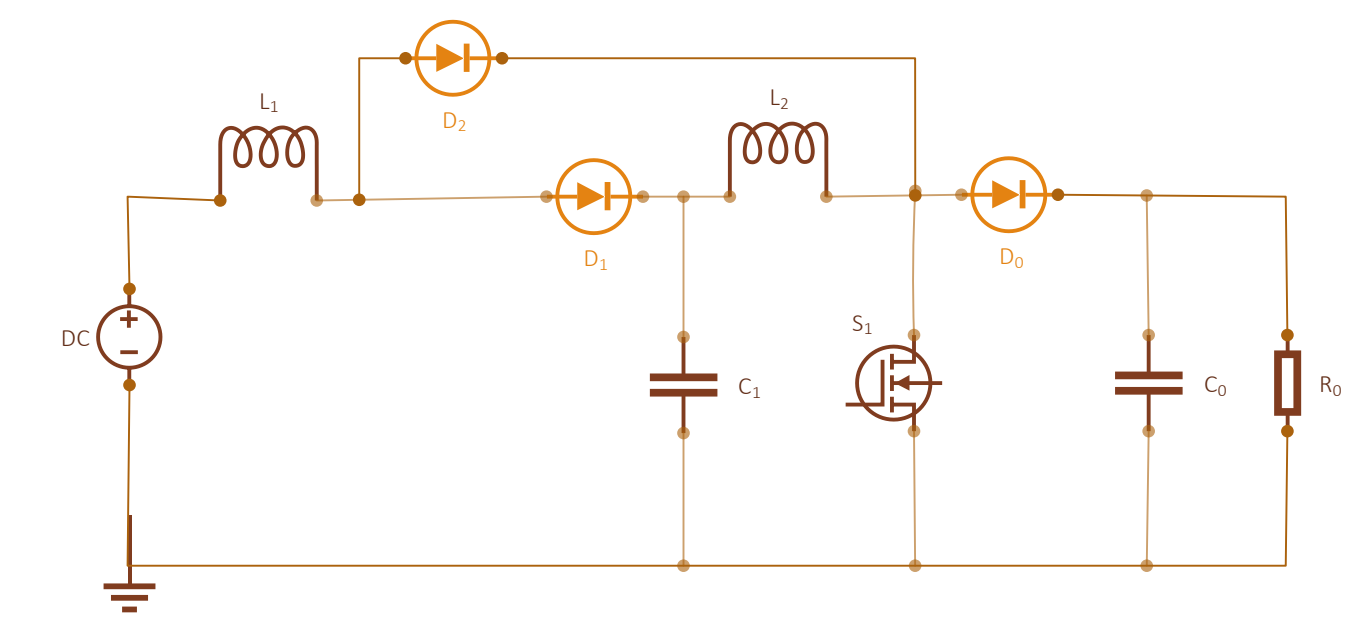

Figure-4 Traditional Quadratic Boost Converter

The voltage gain is 


$$
M=\frac{\mathrm{V}_{0}}{\mathrm{~V}_{\mathrm{s}}}=\frac{1}{(1-D)^{2}}
$$

The main disadvantage of traditional quadratic boost converter is step-up switching structure, which is not suitable because there is no energy storing elements.

\section{Three-level Quadratic Boost Converter}

Three level quadratic boost converter derived from traditional quadratic boost which depicted in figure-5. The advantage of this converter is two switches and two output capacitors which decree the voltage stress across the switches and result output voltage is balanced. The current conducted by switches in this converter is some of currents of both inductors.

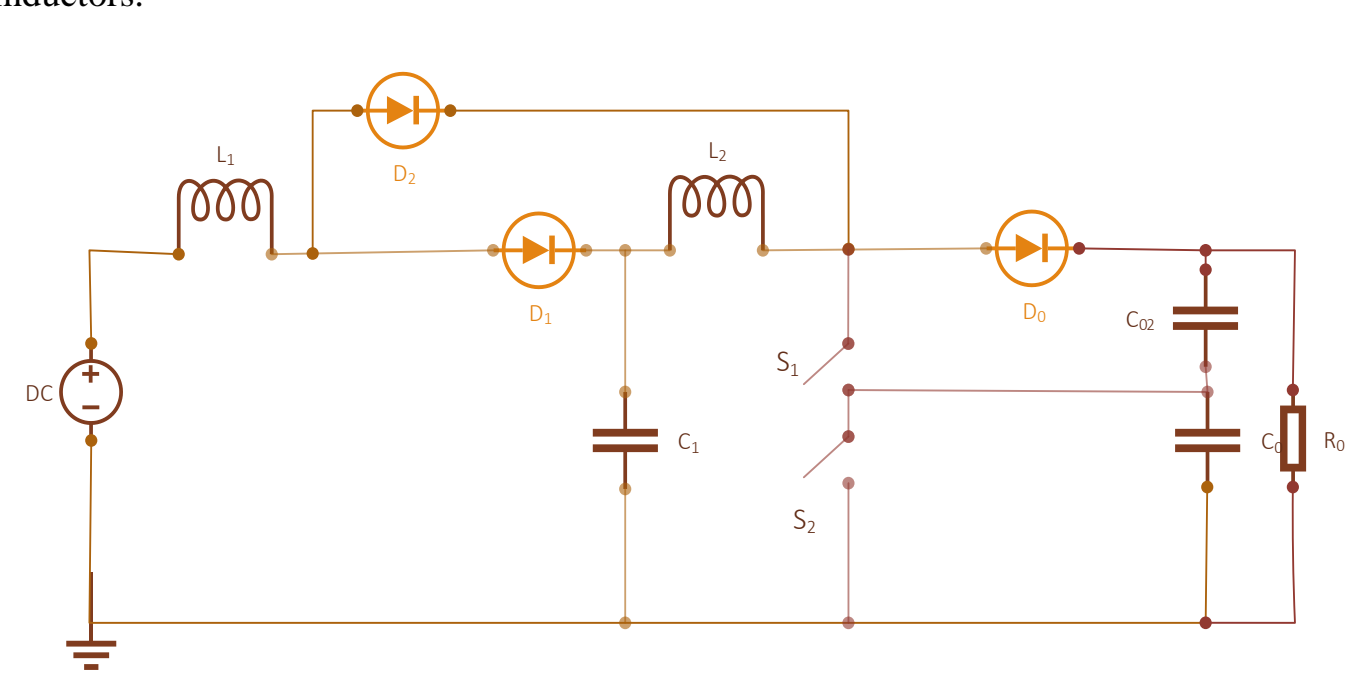

Eigure 5. Modified Quadratic Boost Converter

The main disadvantage of this topology is its transfer function which increases the complexity, control and cost [13]. The voltage gain of this converter is half of conventional quadratie boost converter.

The voltage gaimrequation given below;

$$
M=\frac{\mathrm{V}_{0}}{\mathrm{~V}_{\mathrm{s}}}=\frac{1}{2(1-D)^{2}}
$$

\section{Proposed Topology}

The proposed quadratic boost converter with voltage multiplier (VMC) cell is shown in figure-6. This topology is derived from quadratic boost converter, which consist two additional diodes $\left(\mathrm{D}_{3}-\mathrm{D}_{4}\right)$, capacitors $\left(\mathrm{C}_{2}-\mathrm{C}_{3}\right)$ and inductor $\mathrm{L}_{3}$ which called Voltage multiplier cell (VMC). The main advantage of the proposed topology is its high voltage gain and losses across the semiconductor devices are lower than the output voltage as presented in literature.

\subsection{Working Principle of the Proposed Converter}

The proposed topology has two switching state in 1 PWM signal as shown in Figure $7(\mathrm{a} \& \mathrm{~b})$. The steady state waveform shows below in Figure 8. 


\subsection{State-I:}

When switch $\mathrm{S}$ is $\mathrm{ON}$ as depicted in Figure 7 (a). In this state $\mathrm{D}_{2}, \mathrm{D}_{3}, \mathrm{D}_{4}$ remain OFF, and diode $D_{1}$ is in ON state. DC input voltage source $V_{s}$ provides energy to inductor $L_{1}$ and at same time capacitor $\mathrm{C}_{1}$ deliver stored energy to inductor $\mathrm{L}_{2}$. During this stage capacitor $\mathrm{C}_{1}$ and $\mathrm{C}_{2}$ works in series, the resultant output voltage is sum of both capacitors $\mathrm{Vc}_{2}+\mathrm{V}_{\mathrm{c} 3}=2_{\mathrm{vc}}$, capacitor's stored energy delivered to $\mathrm{L}_{3}$, and the output capacitor during this time is in charging mode. In $1^{\text {st }}$ stage all the inductors current $i_{\mathrm{L} 1}, i_{\mathrm{L} 2}$ and $\mathrm{i}_{\mathrm{L} 3}$ linearly increase.

\subsection{State-II:}

When switch $S$ and diode $D_{1}$ is OFF as shown in Figure $7(b)$, in this stage indactor $L_{1}$ deliver stored energy to capacitor $C_{1}$, and the inductor $L_{2}$ deliver stored energy to capacitor $\mathrm{C}_{1}$ and $\mathrm{C}_{2}$ and load while inductor $\mathrm{L}_{3}$ delivered stored energy to outpat. In this state inductors current $i_{L 1}, i_{L 2}$ and $i_{L 3}$ linearly decrease. At this time all capacitors are in discharging mode to load.

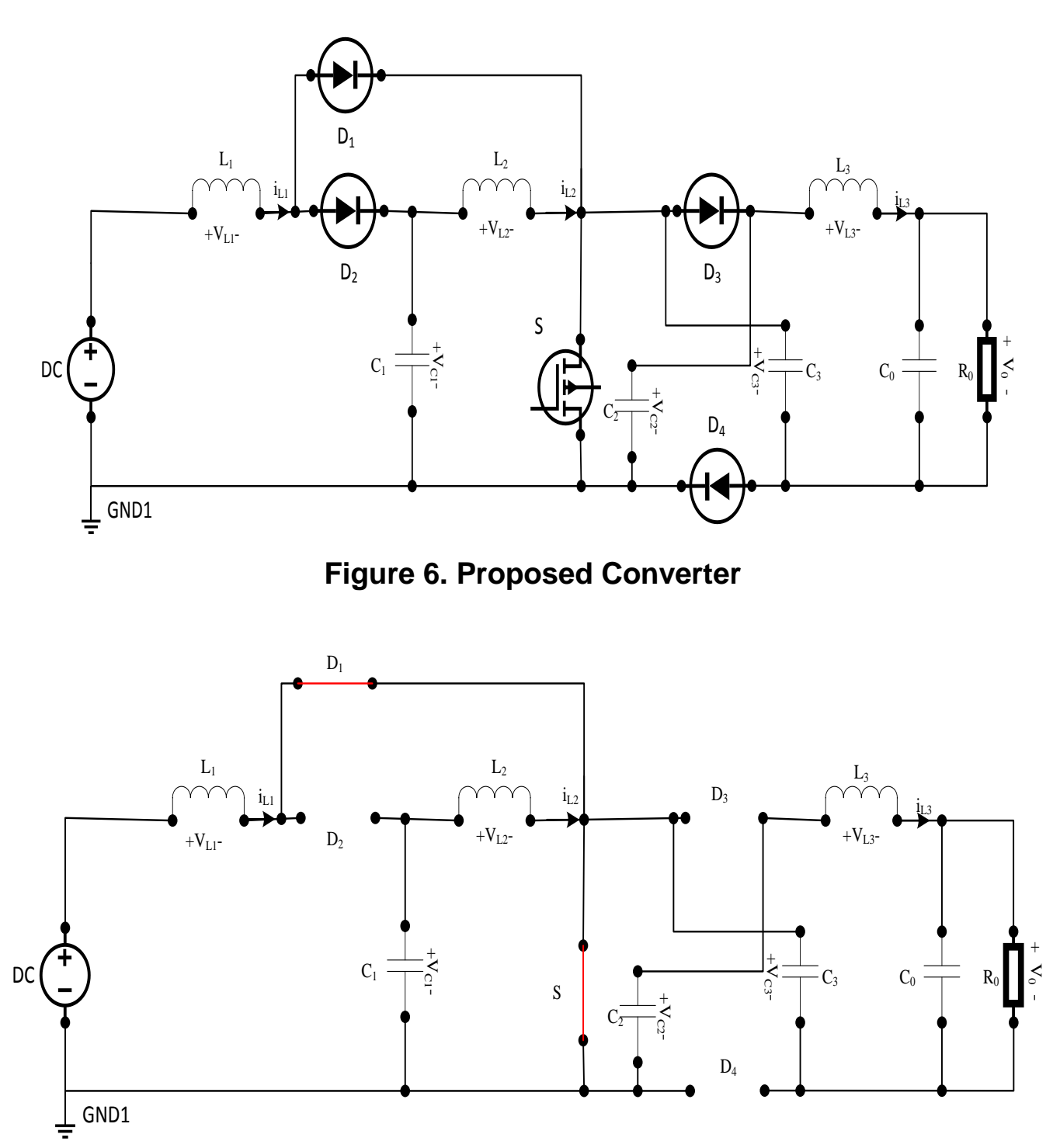

(a) 


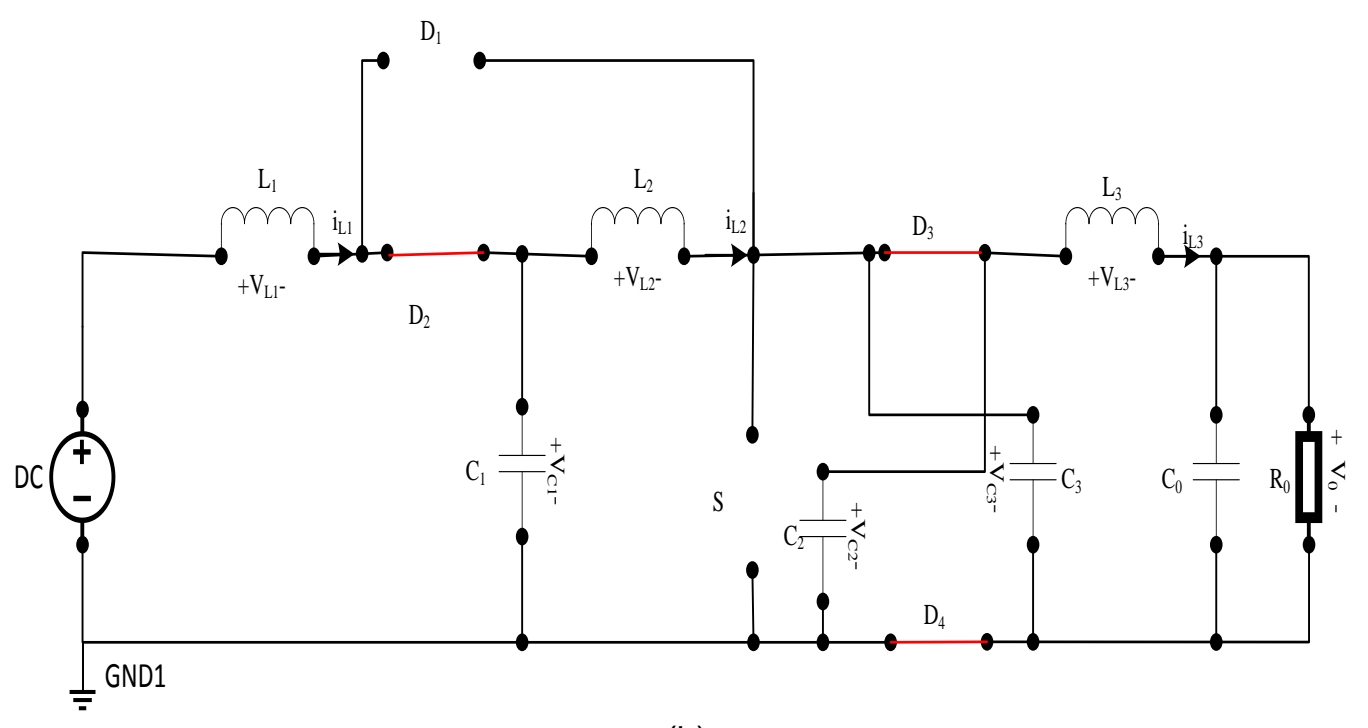

(b)

Figure 7. Switching State of Proposed Conyerter

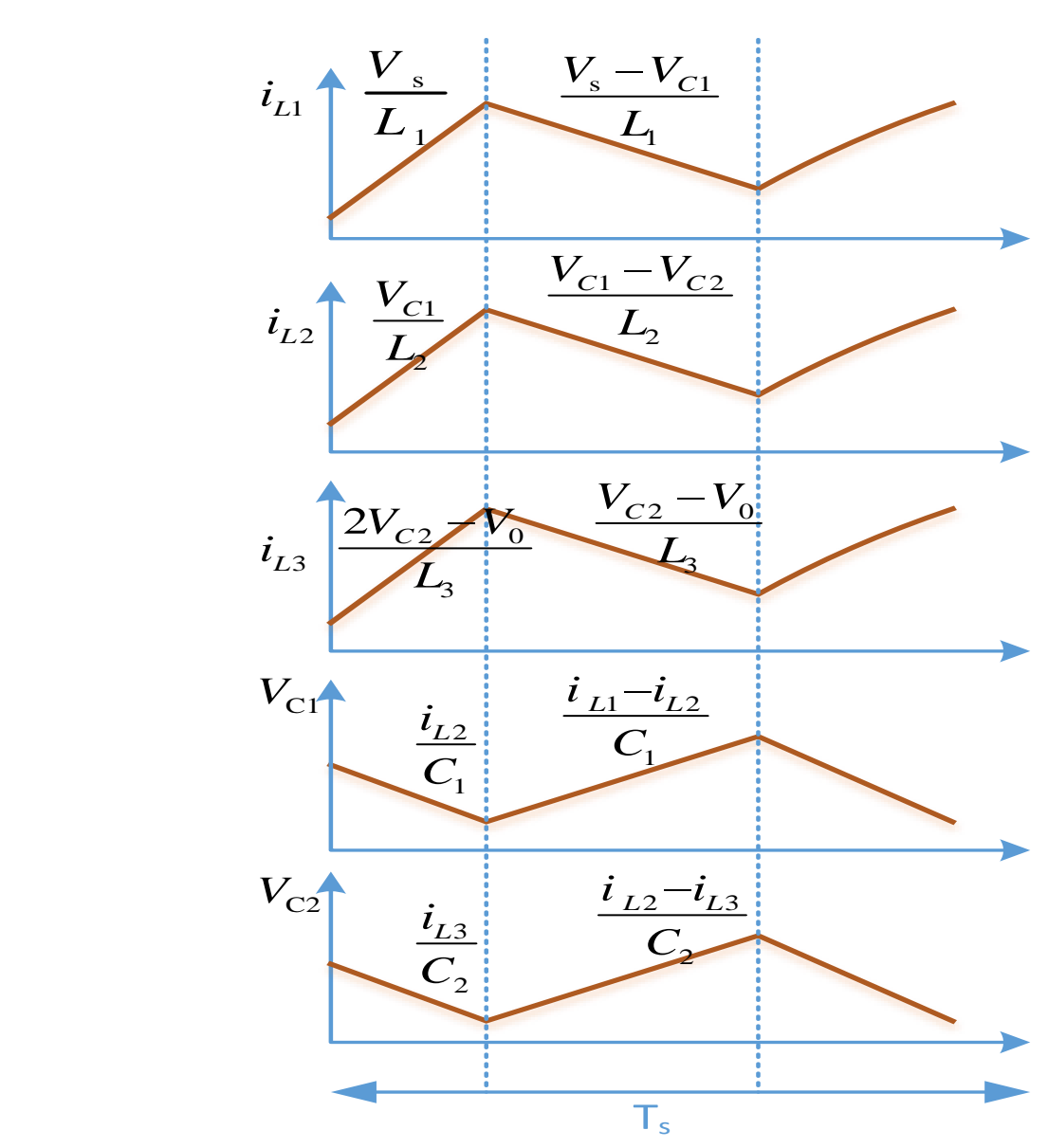

Figure 8. Steady State Waveforms

\subsection{Steady State Analysis of the Proposed Converter}

As it can be observed in Figure 7(a), when the switch S is ON during that stage diode $D_{1}, D_{3}$ and $D_{4}$ are in off mode. The state equation shows in below. 


$$
\left\{\begin{array}{l}
V_{L 1}=V_{S} \\
V_{L 2}=V_{C 1} \\
V_{L 3}=2 v c-V_{0}
\end{array}\right\}
$$

At stage-II we can see figure 7(b), at this stage when switch $\mathrm{S}$ and diode $\mathrm{D}_{2}$ are in OFF mode. The state equation derived below.

\subsection{Conversion Ratio}

$$
\left\{\begin{array}{l}
V_{L 1}=V_{S}-V_{C 1} \\
V_{L 2}=V_{C 1}-V_{C 2} \\
V_{L 3}=V_{C 2}-V_{0}
\end{array}\right\}
$$

Using the principle of inductor volt second balance at inductor $\mathrm{L}_{1}$ we get:

$$
D V_{s} \times f(1-D)\left(V_{s}-V_{c}\right.
$$

After solving the equation (3) we gete.

$$
V_{s}=V_{y}(1-D)
$$

Again using inductor volt balance at inductor $\mathrm{L}_{2}$

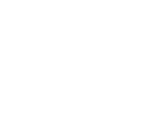

$$
D V_{C 1}+(1-D)\left(V_{c 1}-V_{c 2}\right)
$$

After solving this equation (6) we get,

$$
V_{c 2}=\frac{V_{C 1}}{(1-D)}
$$

After put the $\mathrm{V}_{\mathrm{c} 1}$ Value we get,

$$
V_{c 2}=\frac{V_{S}}{(1-D)^{2}}
$$

Using inductor volt balance at inductor $\mathrm{L}_{3}$,

$$
D\left(2 V_{C}-V_{0}\right)+(1-D)\left(V_{c 2}-V_{0}\right)
$$

After solving the equation (9) we get,

$$
V_{0}=V_{C_{2}}(1+D)
$$


Static gain of proposed topology is,

$$
M=\frac{V_{0}}{V_{S}}=\frac{1+D}{(1-D)^{2}}
$$

\subsection{Voltage Stress Across the Semiconductor Devices}

In state-I the voltage stress across the semiconductor diodes is as below,

$$
\begin{gathered}
V_{D 1-\text { stress }}=\frac{(1-D) V_{0}}{1+D} \\
V_{\text {D3-stress }}=-V_{\mathrm{c} 2}
\end{gathered}
$$

Similarly in state-II the voltage stress of semiconductor defices are

\subsection{Simulation Results and Discussion}

To validate the performance on the proposed converter and others converter which are presented to compare with the proposed topology simulation are done in MATLAB/ Simulink software accoraing to the parameters given in Table 1. The proposed topology results shows in Figure 9. For cormparison other converters output voltages shown in Figure 10.

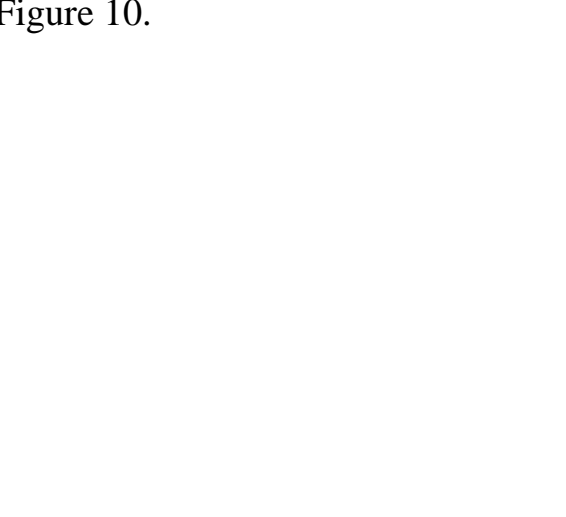



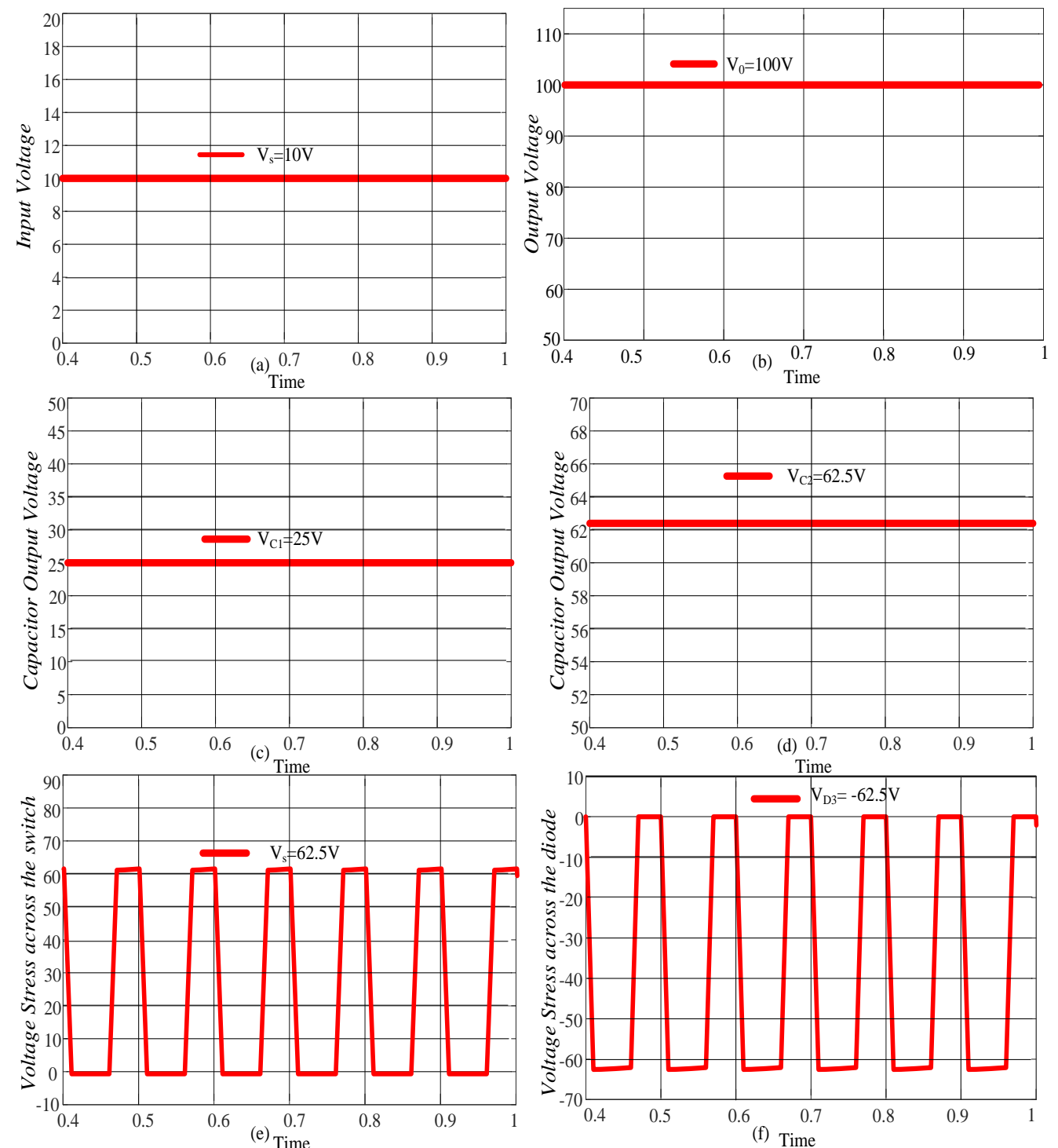

Figure 9. Simulation Results of Proposed Converter. (a) Input Voltage $\left(\mathrm{V}_{\mathrm{s}}\right)$, (b) Output Voltage $\left(V_{0}\right)$, (c \& d) Capacitors Voltage $\left(V_{\mathrm{c} 1}, V_{\mathrm{c} 2}\right)$, (e) Voltages Stress, $\left(V_{s 1}\right)$ and (f) Voltage Stress $V_{D 3}$ of Diode $D \cdot 3$

Table 1. Component List of the Proposed Topology

\begin{tabular}{ccc}
\hline Name of parameter & Symbol & Value \\
\hline Input Voltage & $\mathrm{V}_{\mathrm{S}}$ & $10 \mathrm{~V}$ \\
Output Voltage & $\mathrm{V}_{\mathrm{O}}$ & $100 \mathrm{~V}$ \\
Load Resistance & $\mathrm{R}_{\mathrm{L}}$ & $100 \Omega$ \\
Frequency & $\mathrm{F}_{\mathrm{S}}$ & $100 \mathrm{kHz}$ \\
Filter inductor/phase & $\mathrm{L}$ & $200 \mathrm{uH}$ \\
Capacitors & $\mathrm{C}$ & $10 \mathrm{uF}$ \\
Output capacitor & $\mathrm{C}_{\mathrm{o}}$ & $10 \mathrm{uF}$ \\
Duty ratio & $\mathrm{D}$ & 0.6 \\
\hline
\end{tabular}


Table 2. Voltage Gain Comparison

\begin{tabular}{ccccc}
\hline & Topology Name & $\mathrm{V}_{\mathrm{s}}$ & $\mathrm{V}_{0}$ & $\begin{array}{c}\text { Voltage } \\
\text { gain }\end{array}$ \\
\hline 1 & Proposed topology & $10 \mathrm{~V}_{\mathrm{DC}}$ & $100 \mathrm{~V}$ & $10 \%$ \\
2 & Conventional quadratic boost converter & $10 \mathrm{~V}_{\mathrm{DC}}$ & $62.5 \mathrm{~V}$ & $6.25 \%$ \\
3 & Boost converter with voltage lift cell & $10 \mathrm{~V}_{\mathrm{DC}}$ & $50 \mathrm{~V}$ & $5 \%$ \\
4 & Boost converter with extension cell & $10 \mathrm{~V}_{\mathrm{DC}}$ & $35 \mathrm{~V}$ & $3.5 \%$ \\
5 & Three level quadratic boost converter & $10 \mathrm{~V}_{\mathrm{DC}}$ & 31.5 & $3.15 \%$ \\
6 & Traditional boost converter & $10 \mathrm{~V}_{\mathrm{DC}}$ & $25 \mathrm{~V}$ & $2.5 \%$ \\
\hline
\end{tabular}

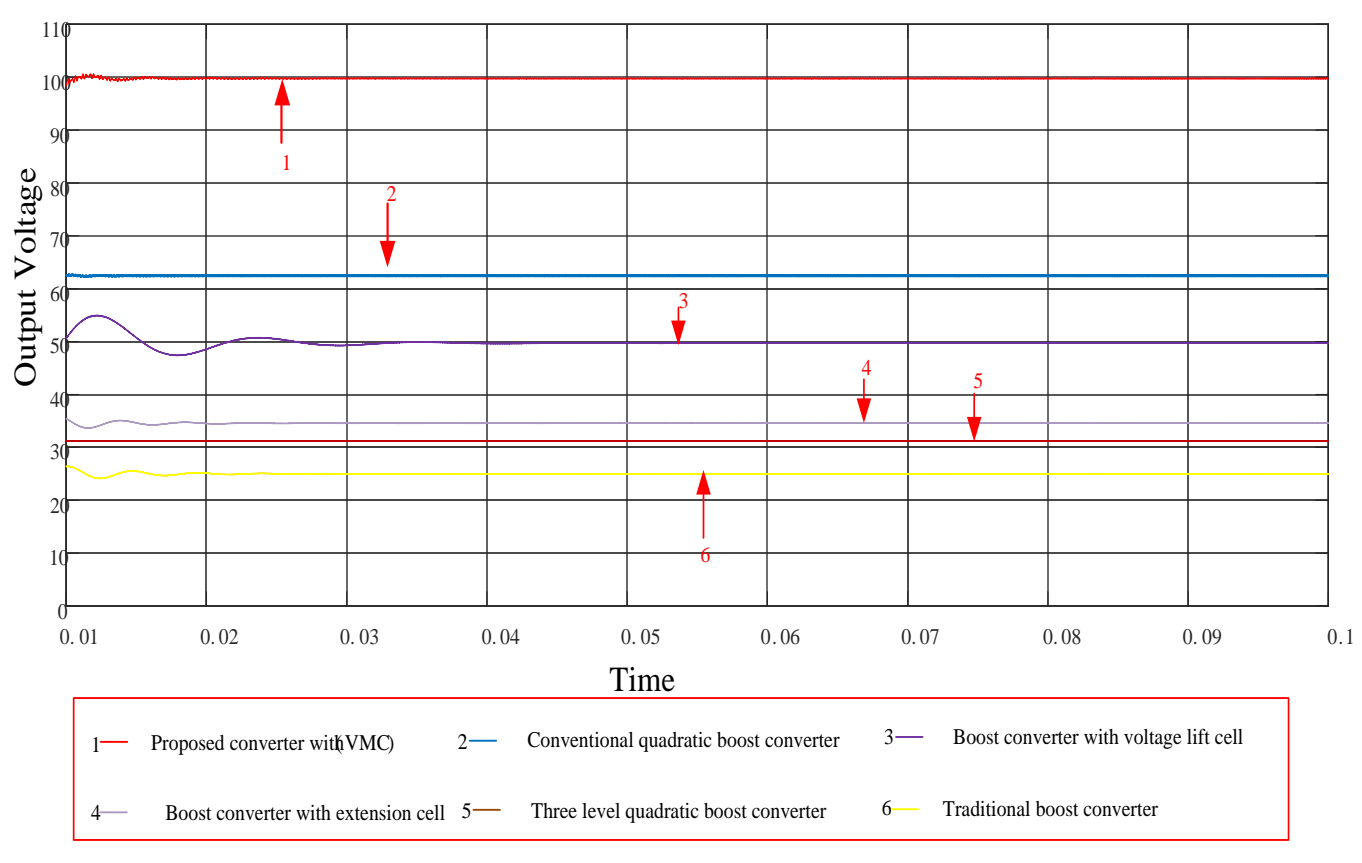

Figure 10. Gomparison Simulation Results

Figure 10 is output yoltages of proposed converter and other modified converters which are explained in Table 2. In Figure 9 authenticate the results and efficacy of the proposed quadratic boost converter with voltage multiplier cell (VMC) simulation results attain in Mat-lab Simulink software according to Table 1. Figure 9 (a) shows the waveforms of input voltage where we can see clearly the input voltage is $10 \mathrm{~V}$ and in figure-9 (b) output voltage is nearly $100 \mathrm{~V}$ which is very near according to voltage gain equation (11). It is prove that the proposed converter can achieve high voltage gain conversion ratio at the low input voltage $10 \mathrm{~V}$ and output voltage is $100 \mathrm{~V}$. Figure-9(c) is waveforms of voltage stress $\mathrm{V}_{\mathrm{s} \text {-stress }}$ across the MOSFET switch $\mathrm{S}$ its clearly shows that the stress of switch is lower than the output voltage. In Figure-9(d) shows the waveforms of the voltage stress across the diode $D_{3}$, it's also clear from figure that the voltage stress of diode $\mathrm{D}_{3}$ is also less than the output voltage when compare to conventional quadratic boost converter. Traditional quadratic boost converter has stresses across the switch and diode is equal to output voltage according to equations $\mathrm{V}_{\mathrm{S} \text {-stress }}=\mathrm{V}_{0}$ and $\mathrm{V}_{\mathrm{D} 3}=-\mathrm{V}_{0}$. Figure $9(\mathrm{e}, \mathrm{f})$ shows the waveforms of the capacitor output voltages across the capacitors $\mathrm{C}_{1}$ and $C_{2}$. The output voltage of $V_{C_{1}}$ is $25 \mathrm{~V}$ and the voltage across the capacitor $C_{2}$ is $62.5 \mathrm{~V}$ which are same according to theoretical equations (5) and (7).

In Figure 10 simulation results carried out at same input voltage 10VDC is given to all the other 5 topologies and including the proposed topology with voltage multiplier cell. In figure-10 output voltages are given, where it can be observe that output voltage of the proposed topology is higher at 100VDC as compare to others output results. In figure-10 we can clearly see that if we use same parameters according to table- 1 the proposed 
quadratic boost converter with voltage multiplier cell (VMC) is higher than other modified converters. The output voltages of proposed converter is $100 \mathrm{~V}$ and the output voltage of traditional boost converter is $25 \mathrm{~V}$, traditional quadratic boost converter is $62.5 \mathrm{~V}$, boost converter with voltage lift cell is $50 \mathrm{~V}$, modified quadratic boost converter is $31.5 \mathrm{~V}$ and boost converter with extension module is $35 \mathrm{~V}$.From simulation results it is clear that the proposed topology quadratic boost converter with voltage multiplier cell (VMC) has advantage over other converters which are presented in literature. This converter is very suitable where we need low input to high output voltages such as photovoltaic (PV) and other application etc.

\section{Conclusion}

A new topology of quadratic boost converter with voltage multiplier cell (VMC) is introduced in this paper. The operation principle of proposed converter and others converter discuss in details. The basic advantage of voltage multiplier cell over the traditional quadratic boost converter and others which discussed in literature has high voltage gain and stress across the switches is lower than the output voltage, which makes appropriate for application where we need the high step up conversion ratio. Furthermore to validate the proposed converter simulation results given in this paper with compression of others converter. Simulation results shows that the proposed converter has much higher voltage gain under the same duty ratio $D=0.0$. The proposed quadratic boost converter with voltage multiplier cell (VMC) is very useful where we Deed low input to high output voltage such as photovoltaic (PV) and fuel cell (FC) etc.

\section{References}

[1] M. Zeeshan Malik, A. Farooq, A. Ali and Go Chen, "A DC-DC Boost Converter with Extended Voltage Gain”, DOI: 10.1051/MATEC Web of Conferences/20164007001.

[2] http://www.erec.org/fileadmin/erec_docs/Documents/P.ublications/Renewable_Energy_Technology_Ro a dmap.pdf, Renewâble Enęrgy Technology Roadmap 20\% by (2020) [Online]

[3] M. Amirabadi, A. Balakrishnan, H. Toliyat and W. Alexander, IEEE Trans. Ind. Electron, vol. 61, (2014), pp. 281-291.

[4] Soft-Switching AC-Link Three-Phase AC-AC Buck-Boost Converter, IEEE Trans. Ind. Elec. 62, (2015).

[5] F. S. Garcia, J. A. Pomilio and G. Spiazzi, "Comparison of Non-Insulated, High-Gain, High-Power, Step-Up DC-DC Converters', IEEE, (2012).

[6] A. Farooq, Z. Malik, Dv Qu, Z. Sun and G. Chen, "A Three-Phase Interleaved Floating Output Boost Converter", Hindaw Publishing Corporation Advances in Materials Science and Engineering Volume 2015, Article W 409674, 8 pages http://dx.doi.org/10.1155/2015/409674.

[7] Z. H. Shi, K. W.'E. Cheng and S. L. Ho, "Static performance and parasitic analysis of tapped-inductor converters TET Power Electronics, vol. 7, no. 2, (2014), pp. 366-375.

[8] C. Feeney, C. Fitzgerald and M. Duffy, "Investigation of coupled inductors in a phase interleaved boost module integrated converter", Proceedings of the IEEE 5th International Symposium on Power Electronics for Distributed Generation Systems (PEDG '14), Galway, Ireland, (2014) June, pp. 1-5.

[9] S-K. Changchien, T.-J. Liang, J.-F. Chen and L.-S. Yang, "A cascaded high step-up DC-DC converter with single switch for microsource applications", IEEE Trans. Ind. Electr., vol. 26, no. 4, (2011), pp. 1146-1153.

[10] R. W. Erickson and D. Maksimovic, "Fundamentals of Power Electronics", USA: Springer, (2000).

[11] F. L. Luo and H. Ye, "Positive output super-Lift sonverters", IEEE Transactions on Power Electronics, vol. 18, no. 1, (2003) January, pp. 105-113.

[12] D. Maksimovic and S. Cuk, "Switching converters with wide DC conversion range", IEEE Transactions on Power Electronnics, vol. 6, no. 1, (1991) January, pp. 151-157.

[13] J. A. Morales-Saldana, R. Galarza-Quirino and J. Leyva-Ramos, "Multiloop controller design for a quadratic boost converter", IET Power Applications., vol. 1, no.3, pp. 362-367, (2007) May.

[14] J. Leyva-Ramos, M. G. Ortiz-Lopez, L. H. Diaz-Saldierna and J. A. Morales-Saldana, "Switching regulator using a quadratic boost converter for wide DC conversion ratios", IET Power Electronics, vol. 2, no.5, (2009) September, pp. 605-613.

[15] R. Kadri, J. P. Gaubert and G. Champenois, "Performance analysis of transformless single switch quadratic boost converter for grid connected photovoltaic systems", IEEE Electrical Machines Conference, (2010), pp. 1-7. 
[16] L.-S. Yang, T.-J. Liang, H.-C. Lee e J.-F. Chen, "Novel High Step-Up DC-DC Converter With CoupledInductor and Voltage-Doubler Circuits," IEEE Transactions on, vol. 58, n. 9, pp. 4196- 4206, 2011.

\section{Authors}

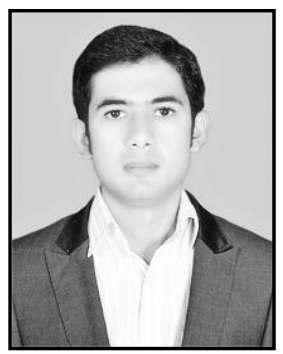

Muhammad Zeeshan Malik Got his Master Degree in Electrical Engineering From Chongqing University China in 2012. From 2013 he joined the electrical engineering department of Zhejiang University as a $\mathrm{PhD}$ Scholar. His research interests in the area of Power Electronics with focus on dc-dc converters and Renewable Energy Systems.

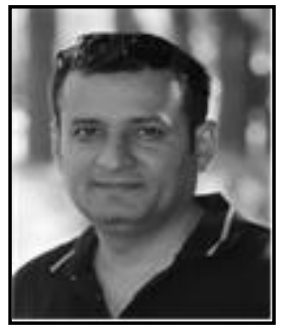

Amjad Ali (MIET, IEEE ); received his M.Se. degree in Electronics from University of Sindh Jamshoro Pakistan, Currently working toward the Ph.D. degree in electrical engineering from college of Electrical Engineering Zhejiang University, Hangzhou. His research interests include renewable energy technologies, microgrid control and energy management \& energy efficiency.

Qunwei Xu was born in Hyzhou, China, 1989 . He received the B.S. degree in electrical engineering from the Wuhan. University in 2008. Since 2008, he has been studying for the Ph.D. degree in electrical engineering from the Zhejiang University. His research interests include power electonjes, power quality issues, and digital control systems.

Guozhu Chen, was bom in Hubei, China, in 1967. He received his B.S. degree in Electrical Engineering from Ltangzhou Commerce University, Hangzhou, China, in 1988, and the M.S. and PhD. degrees in Electrical Engineering from Zhejiang University, Hangzhou, China, in 1992 and 2001 respectively. Since 1992, he has been with the faculty of the College of Electrical and Engineering at Zhejiang University, China, where he was an Associate Professor from 2000 to 2005, and a Professor since 2005. From January 2001 to April 2004, he was a Visiting Scholar in the University of California, Irvine, USA. His current research interests include high-power electronics applications and their digital control; active power quality control such as APF, UPQC, SVC, dSTATCOM and dFACTS; grid connection of renewable energy/distributed power generation; and power electronic system integration. He holds more than 20 Chinese patents, and has contributed to more than 180 academic papers. 
International Journal of Smart Home

Vol. 10, No. 8 (2016)

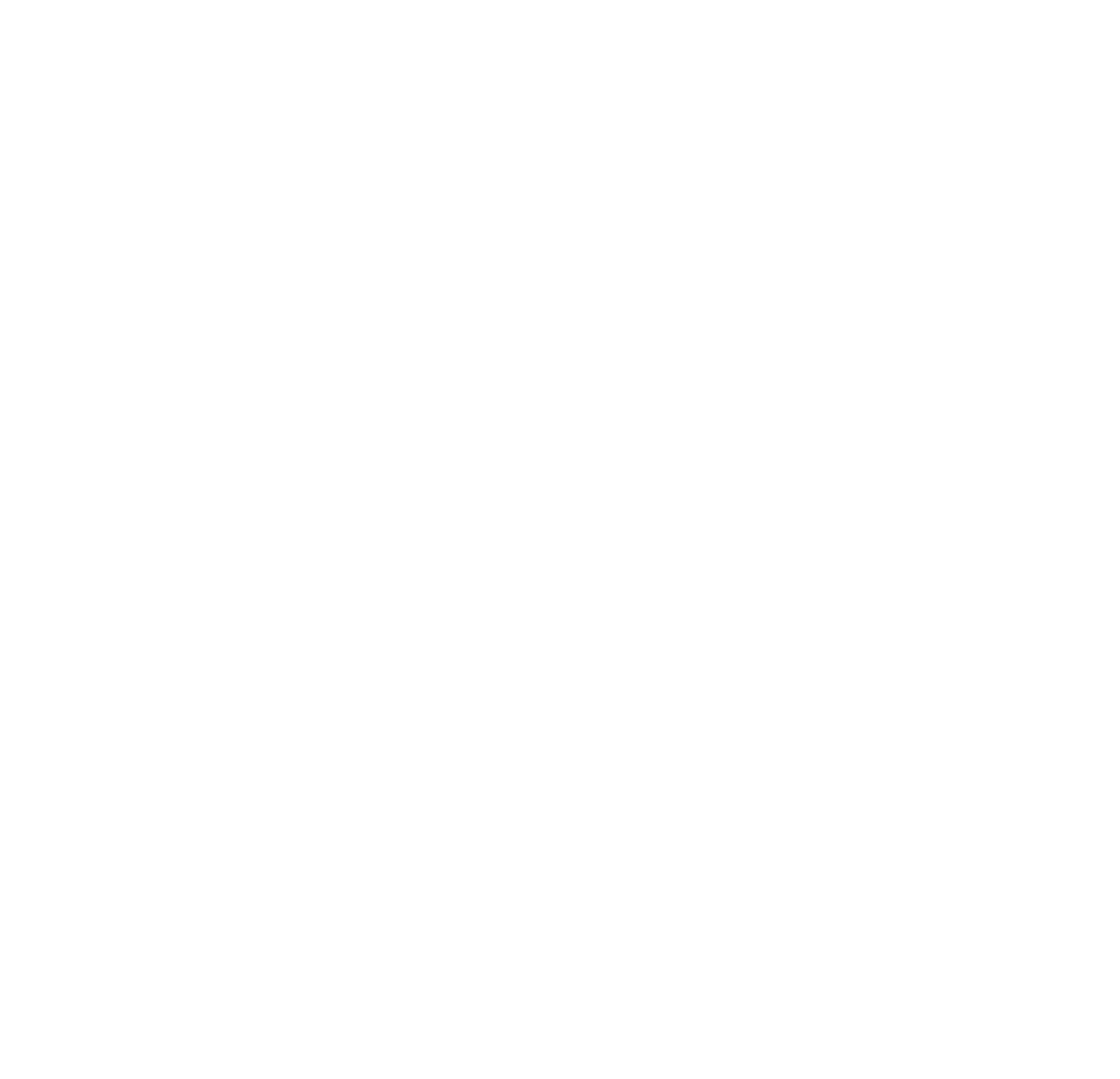

